\title{
Phytosanitary Quality of Genotypes of Wheat Seeds Used Northern Paraná State
}

\author{
Jacqueline Dalbelo Puia ${ }^{1}$, Leandro Camargo Borsato ${ }^{2}$, Marilize Cristina Gonçalves de Oliveira ${ }^{2}$, \\ Adriano Thibes Hoshino ${ }^{1}$, Marcelo Giovanetti Canteri ${ }^{1} \&$ Sandra Cristina Vigo ${ }^{2}$ \\ ${ }^{1}$ Universidade Estadual de Londrina, Londrina, Brazil \\ ${ }^{2}$ Instituto Agronômico do Paraná, Londrina, Brazil \\ Correspondence: Jacqueline Dalbelo Puia, Universidade Estadual de Londrina, Londrina, PR, Brazil. Tel: \\ 55-43-3376-2114. E-mail: puia.agro@gmail.com
}

Received: February 13, $2020 \quad$ Accepted: April 11, $2020 \quad$ Online Published: May 15, 2020

doi:10.5539/jas.v12n6p57 URL: https://doi.org/10.5539/jas.v12n6p57

\begin{abstract}
Wheat seeds can be infested and/or infected by microorganisms that might cause deterioration of this propagation structure. The aim of this study was to evaluate the health quality of sixteen wheat genotypes grown in northern Paraná. Therefore, seeds of each genotype were submitted to the blotter test with 16 repetitions, 400 seeds per sample, for phytosanitary quality evaluation. The identification of the fungi was performed based on their morphological characteristics and quantified data. The results revealed variations in incidence, with 20 fungi genera in the analyzed samples. The fungi Rhizopus sp., Aspergillus sp., Penicillium sp. and Bipolaris sp. were found in $100 \%$ of the analyzed samples, while Mucor sp. and Alternaria sp. were in $89 \%$ and $78 \%$ of the samples, respectively. The main pathogens that cause diseases in the aerial part of wheat were not found, or were low incidence in all materials analyzed. The pathogens with the highest incidence associated with wheat seeds were groups of storage fungi and known to produce mycotoxins.
\end{abstract}

Keywords: Triticum aestivum L., seed pathology, blotter test

\section{Introduction}

Wheat (Triticum aestivum L.) is the cereal of the most economic importance worldwide, with over 600 million tons produced annually. In southern Brazil, it is most important chief winter crop, with annual production ranging from 5 to 6 million tons, and a consumption of around 10 million tons (Silva et al., 2011; CONAB, 2020).

During the development and maturation of plants in the field, these are attacked by fungi and other phytopathogenic organisms, resulting in diseased plants, seed quality is essential for the proper establishment of the plant population in the field, its full development and production (Dhingra, 1985; Souza et al., 2007). The vast majority of these fungi are agents of leaf stains and transmitted by seeds, from which they return to air organs through the transmission process (Reis \& Casa, 1998; McMullen et al., 2012; Dweba et al., 2017).

The main difficulty encountered by wheat producers in southern Brazil is excess rainfall during the crop development cycle, covered days favorable to the occurrence and intensity of leaf diseases, directly interfering with the potential of phytosanitarial quality of seeds (Reis, 2001). As leaf diseases in the Southern Region of Brazil that deserve to be highlighted are as caused by idiode (Blumeria (Sin. Erysiphe) graminis (DC) Speerf. sp. tritici Em. Marchal), a rust of the leaf, (Puccinia triticina Eriks), the yellow stain (Drechslera tritici-repentis (Died) Drechs.), and a septoriosis (Septoria nodorum (Berk. Berk.) (Reis \& Casa, 2005).

The increase in the intensity of diseases caused by these fungi in a crop is directly related to the use of infected seeds, monoculture and no-tillage. The majority of the necrotrophic fungi survive in the seed, often in the form of dormant mycelium, and sometimes infesting them. The higher the incidence of the pathogen in the seeds, the higher the percentage of outbreaks in the field and the earlier the epidemic begins (Menten, 1995; Kobayasti \& Pires, 2011).

The presence of phytopathogens in wheat seeds has been constantly reported, and this association has been responsible for the reduction of seed physiological quality, introduction, dissemination and early transmission of 
pathogens to progeny. Therefore, this study aimed to investigate the phytosanitary quality of seeds of 16 wheat genotypes planted in the northern region of the state of Paraná, obtained in the 2018 crop.

\section{Method}

This study was performed at the Seed Pathology Laboratory, Agronomic Institute of Paraná (IAPAR), Londrina. The wheat genotypes used in this study are materials grown throughout the northern region of Paraná. These materials were collected in seed production field during the 2018 harvest in the northern region of Paraná. The genotypes used were, BRS Gaivota, BRS Graúna, BRS Gralha azul, BRS Tangará, BRS Pardela, BRS Sabiá, BRS Sanhaço, IPR Taquari TM, TBIO Mestre, TBIO Sintonia, FPS Virtude, LD 141103, LD 142114, LD 152109, WT 11167 and WT 13086. Field collected seed samples from each genotype were submitted to the sanity test by the Blotter test and vigor test. The seeds remained in paper packaging and were stores in cold room conditions at 7 to $10{ }^{\circ} \mathrm{C}$ and $30 \%$ relative humidity to decrease deterioration.

Each sample was partitioned into 16 repetitions, totaling 400 seeds per genotype, in which 25 seeds per gerbox were distributed equidistantly.

The seeds were incubated in a climate chamber with a temperature of $25 \pm 2{ }^{\circ} \mathrm{C}$ and a photoperiod of 12 hours, for seven days. After incubation time, identification was performed, based on characteristics described by Barnett and Hunter (1998); Leslie and Summerell (2008); and Warham et al. (1996), and recording the number of phytopathogens present as well as the amount of infested seeds. The quantification of phytopathogens in wheat seeds was performed with the aid of a stereoscopic microscope (Stemi 2000-C, Zeiss), with a 40X magnification and optical microscope (Primostar, Zeiss). Seeds with presence of conidiophores and/or spores fungi were considered infested. Results were expressed as a percentage (MAPA, 2003).

Data were submitted to analysis of variance and averages were compared by the Scott-Knott test at $5 \%$ probability.

\section{Results and Discussion}

Twenty genera of phytopathogenic fungus were recorded, in addition to an unidentified fungus on the seeds of the 16 wheat genotypes analyzed, and the number of pathogens varied in diversity and their respective incidence varied according to genotype (Table 1). 
Table 1. Incidence (\%) of different pathogens on seeds of 16 wheat genotypes, detected by Blotter test, without asepsis, Londrina, 2018

\begin{tabular}{|c|c|c|c|c|c|c|c|c|c|c|c|c|c|c|c|c|c|c|}
\hline \multirow[b]{2}{*}{ Pathogens } & \multicolumn{16}{|c|}{ Wheat (Triticum aestivum $\mathrm{L}$.) genotypes } & \multirow[b]{2}{*}{$\begin{array}{l}R F^{1} \\
(\%)\end{array}$} & \multirow[b]{2}{*}{$\mathbf{I}^{2}$} \\
\hline & 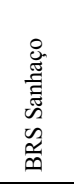 & 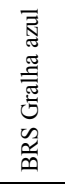 & 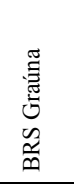 & 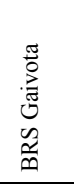 & 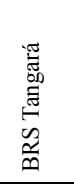 & 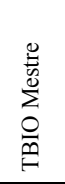 & $\begin{array}{l}\frac{\pi}{0} \\
\frac{0}{\pi} \\
\text { a } \\
0 \\
\frac{n}{n}\end{array}$ & $\begin{array}{l}\stackrel{\Xi}{\Xi} \\
\stackrel{\sim}{ \pm} \\
\Xi\end{array}$ & 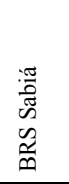 & $\begin{array}{l}\stackrel{a}{0} \\
\stackrel{\sqrt{n}}{a} \\
\text { a }\end{array}$ & $\begin{array}{l}\hat{6} \\
\equiv \\
\vdots \\
3\end{array}$ & 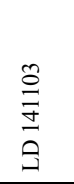 & 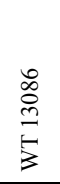 & 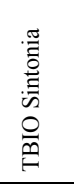 & 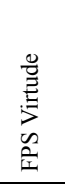 & 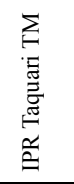 & & \\
\hline Rhizopus sp. & 31.25 & 2.75 & 1.75 & 1 & 28 & 62 & 14.25 & 11.75 & 17.75 & 8.25 & 50 & 63.75 & 21 & 24.25 & 11.5 & - & 349.25 & 15 \\
\hline Aspergillus sp. & 4 & 2 & 10.75 & 4.25 & 15.25 & 2.75 & 9.5 & 6 & 6.25 & 11.25 & 24.25 & 7 & 3.5 & 24.75 & 2.75 & 0.75 & 135.00 & 16 \\
\hline Mucor sp. & 1 & 4.25 & 28.5 & 32.25 & 1.25 & - & 8.25 & 3.75 & 3 & 17 & - & - & 5.5 & 12.5 & 5 & - & 122.25 & 12 \\
\hline Alternaria $\mathrm{sp}$. & 22 & 23 & 3.5 & - & 4.75 & - & 8 & 12.5 & 2 & - & - & - & - & - & - & 5.75 & 81.50 & 8 \\
\hline Penicillium sp. & 0.5 & 3.25 & 5.25 & 2.75 & 7.25 & 5.75 & 0.25 & 0.75 & 6.25 & 8.25 & 11 & 3 & 2.25 & 3.25 & 6 & - & 65.75 & 15 \\
\hline Pyricularia grisea & $-3^{3}$ & 0.25 & - & - & - & - & - & - & - & - & - & - & & - & - & 59 & 59.25 & 2 \\
\hline Bipolaris sp. & 8 & 1.5 & 1 & 2.25 & 0.75 & 0.25 & 1.75 & 3.5 & 1.25 & 1 & 0.25 & 0.25 & 4 & 0.25 & 2 & - & 28.00 & 15 \\
\hline $\begin{array}{l}\text { Fusarium } \\
\text { verticillioides }\end{array}$ & 2.25 & 1.75 & - & 0.25 & & - & 0.75 & 8.25 & 0.25 & 2.5 & - & - & - & 2.5 & - & 6.5 & 25.00 & 9 \\
\hline Nicrospora sp. & - & - & 0.25 & - & - & - & - & - & - & - & - & - & - & - & - & 11 & 11.25 & 2 \\
\hline Trichoderma sp. & 0.75 & 0.75 & - & - & - & - & - & 6.25 & - & 2.75 & - & - & - & - & - & 0.5 & 11.00 & 5 \\
\hline Curvularia sp. & - & - & 2 & 0.5 & 0.25 & - & - & - & 0.5 & - & 1.5 & - & - & 1 & 1 & - & 6.75 & 7 \\
\hline Cladosporum sp. & - & 1.25 & - & 1.75 & - & - & - & - & - & - & - & - & - & - & - & - & 3.00 & 2 \\
\hline Chaetomium sp. & - & - & - & - & - & - & - & - & 0.25 & 0.5 & 0.25 & - & 0.5 & - & - & - & 1.50 & 4 \\
\hline Fusarium poae & - & 0.5 & - & - & - & - & 0.25 & - & - & - & - & - & - & - & - & 0.5 & 1.25 & 3 \\
\hline Phoma sp. & - & - & - & - & 0.25 & - & - & 0.75 & - & - & - & - & - & - & - & - & 1.00 & 2 \\
\hline Bipolaris spicifera & - & - & - & - & - & - & - & - & - & 0.25 & - & - & - & - & - & - & 0.25 & 1 \\
\hline Drechslera sp. & - & - & - & - & - & - & - & - & 0.25 & - & - & - & - & - & - & - & 0.25 & 1 \\
\hline Fusarium sp. & - & 0.25 & - & - & - & - & - & - & - & - & - & - & - & - & - & - & 0.25 & 1 \\
\hline Periconia sp. & 0.25 & - & - & - & - & - & - & - & - & - & - & - & - & - & - & - & 0.25 & 1 \\
\hline Acremonium sp. & - & - & - & - & 0.25 & - & - & - & - & - & - & - & - & - & - & - & 0.25 & 1 \\
\hline Unidentified fungus & - & 1.25 & 0.25 & 0.5 & 0.75 & - & 9 & 0.25 & 0.25 & 0.25 & 0.5 & - & - & 0.75 & - & 13.75 & 27.50 & 11 \\
\hline Diversity & 9 & 13 & 9 & 9 & 10 & 4 & 9 & 10 & 11 & 10 & 7 & 4 & 6 & 8 & 6 & 8 & 930.50 & - \\
\hline
\end{tabular}

Note. ${ }^{1}$ Relative frequency (RF), ${ }^{2}$ Incidence in genotypes (I), ${ }^{3}$ Absence of Phytopathogen (-).

The fungi found associated with the seeds were Aspergillus sp., Rhizopus sp., Penicillium sp., Bipolaris sp. were found in all wheat cultivars, followed by Mucor sp., Fusarium verticillioides, Alternaria sp. and Curvularia sp., which were recorded in 12 and 7 cultivars, respectively. These fungi together represented $87.4 \%$ of the phytopathogens recorded. Moreover, Rhizopus sp. and Aspergillus sp. were highly frequent, occurring in $37.5 \%$ and $14.5 \%$ of all seeds evaluated. In contrast, Penicillium sp. and Bipolaris sp., were found in only $7.07 \%$ and $3.01 \%$ of the seeds, respectively.

The fungus Rhizopus sp. had a higher incidence in the genotypes LD 141103, TBIO Mestre, WT 11167, BRS Sanhaço, BRS Tangará and TBIO Sintonia, which ranged from $63.7 \%$ to $24.2 \%$. On the other hand, Aspergillus sp. had higher incidence in the TBIO Sintonia, WT 11167 and BRS Tangará genotypes (24.7\% to $15.3 \%)$.

Regarding the genotypes BRS Gaivota, BRS Graúna and the lineage LD 152109, Mucor sp. was the fungus with higher incidence. Finally, Alternaria sp. were found in $23 \%$ and $22 \%$ of seeds of the genotypes BRS Gralha azul and BRS Sanhaço, respectively.

Trichoderma sp., Cladosporum sp., Chaetomium sp., Fusarium poae, Phoma sp., Bipolaris spicifera, Drechslera sp., Fusarium sp., Periconia sp. and Acremonium sp. were also found associated with wheat seeds, however, these fungi were present in few genotypes and with low incidence $(\leq 0.5 \%)$.

The highest diversity of pathogens were found in the genotype BRS Gralha azul, which had 13 different pathogens, followed by BRS Sabiá with 11 fungi. Twelve different pathogens were found in the genotypes BRS Tangará, LD 142114 and LD 152109. On the other hand, the cultivars LD 141103 and TBIO Mestre presented the lowest diversity (4), with predominance of the fungus Rhizopus sp. affecting $63.7 \%$ and $62 \%$ of the seeds, respectively.

Although the presence of fungi such as Phoma sp. and Bipolaris sp. was not constant, it indicates the transport and association of disease-causing pathogens in several crops, causing economic damage, whether in grains or 
seeds. The materials that presented the highest incidence of Phoma sp. were LD $142114(0.75 \%)$ and BRS Tangará $(0.25 \%)$. Genotype LD 152109 was the only one to present the fungus Bipolaris sp. at $0.25 \%$ incidence.

Fungi of secondary importance such as Curvularia sp., Cladosporum sp., Mucor sp., Nigrospora sp., Trichothecium sp., Periconia sp., and Rhizopus sp. are part of the complex of grain-staining pathogens (Celano, Machado, Jaccoud, \& Guimarães, 2012). The genotypes BRS Graúna (2\%), WT 11167 (1.5\%), TBIO Sintonia and FPS Virtude (1\%), BRS Gaivota and BRS Sabiá $(0.5 \%)$ and BRS Tangará $(0.25 \%)$ incidence of the fungus Curvularia sp. Genotypes that presented incidence of the fungus Cladosporum sp. were BRS Gaivota (1.75\%) and BRS Gralha azul (1.25\%). The pathogen Mucor sp. showed a higher incidence in BRS Gaivota materials $(32.25 \%)$ and BRS Graúna (28.5\%). The pathogen Nigrospora sp. showed a higher incidence in the genotype IPR Taquari TM (11\%). Genotypes LD 142114 (6.25\%) and LD 152109 (2.75\%) presented a higher incidence of Trichothecium sp., Periconia sp., presented incidence only in the genotype BRS Sanhaço (0.25\%). Rhizopus sp. showed a higher incidence in genotypes LD 141103 (63.75\%), TBIO Mestre (62\%), WT 11167 (50\%), BRS Sanhaço (31.25\%) and BRS Tangará $(28 \%)$.

The pathogen Penicillium sp., showed a higher incidence in genotypes WT 11167 (11\%), LD 152109 (8.25\%), BRS Tangará (7.25\%) and BRS Sabiá (6.25\%). Fusarium sp., presented a higher incidence in genotypes LD $142114(8.25 \%)$ and IPR Taquari TM (6.5\%).

The main group of fungi, known to produce mycotoxins, include species of Alternaria sp., Aspergillus sp., Penicillium sp. and Fusarium sp., however, the three latter are the dominant ones (Fisher et al., 2012). Additionally, Alternaria sp., Cladosporium sp. and Fusarium sp. are the most common field fungi (Vecchia \& Castilhos-Fortes, 2007). The materials that presented the highest incidence of Alternaria sp. were BRS Gralha azul $(23 \%)$, BRS Sanhaço (22\%) and LD 142114 (12.5\%). Aspergillus sp. presented greater focus on the materials of TBIO Sintonia (24.75\%) WT 11167 (24.25\%) and BRS Tangará (15.25\%). Penicillium sp. in genotypes LD 142114 (8.25\%) and IPR Taquari TM (6.5\%). Fusarium sp., in genotypes LD $142114(8.25 \%)$ and IPR Taquari TM (6.5\%).

The presence of the fungi Rhizopus sp., Mucor sp. and Alternaria sp., which are typically decay fungi, stands out among as causative agents of root rot and leaf spots of various crops. Storage time under conditions where there is some seed-associated pathogen leads directly to loss of seed germination percentage (Casa et al., 2012).

The fungi Aspergillus sp. and Penicillium sp. are associated with seed deterioration, which is often related to inadequate storage conditions, however, contamination can still occur in the field soon after harvesting (Machado, 1982). In contrast, the fungus Bipolaris sp., may be associated with diseases such as yellow spot [Bipolaris sorokiniana (Sacc.) Shoemaker], which causes serious damage to wheat crop, with up to $20 \%$ crop losses (Brancão et al., 2008).

It can be evidenced the presence of fungi of the genera Fusarium, Aspergillus and Penicillium associated with seeds, these when present in seeds and grains, produce secondary metabolic, called mycotoxins, substances capable of damage cause on human and animal health (Freire et al., 2007).

Leaf stain caused by $B$. sorokiniana is considered a disease of great importance to wheat crop, with yield losses of $20-80 \%$. According to Barros et al. (2006) in very favorable conditions, the disease occurs throughout the crop cycle, infected seeds is the main survival mechanism of the fungus. In stored seeds, the fungus has the ability to survive as mycelium, in the endosperm of the seed and colonize the root system until it reaches the shoot (Neergaard, 1979; Kobayasti \& Pires, 2011).

The highest percentages of seeds with phytopathogens were found in the genotypes WT 11167 (88\%) and IPR Taquari TM (86.3\%), and were not statistically different by the Scott-Knott test, while the lowest percentage of seeds with phytopathogens occurred in BRS Gralha azul, WT 13086, BRS Sabiá, FPS Virtude with an incidence ranging between $41.5 \%$ and $28 \%$, respectively (Figure 1 ). 


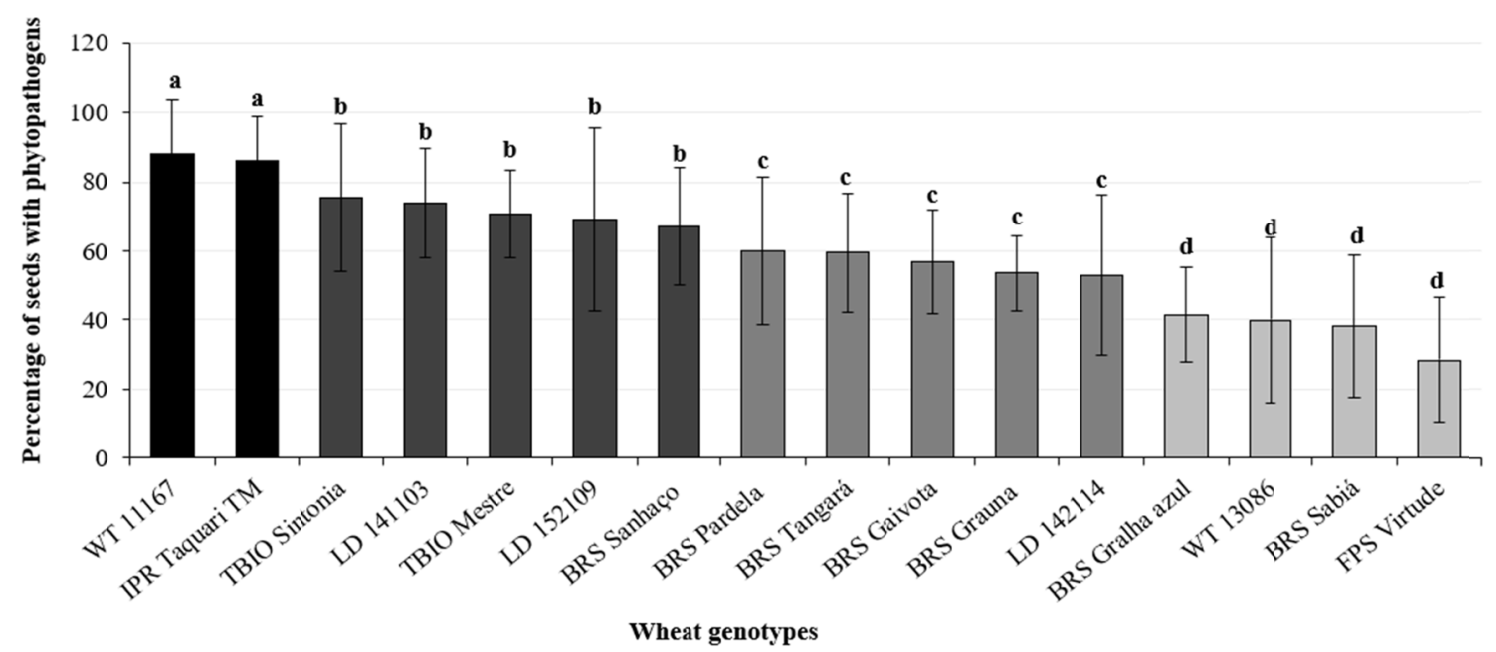

Figure 1. Percentage of phytopathogens detected in wheat seeds (unprocessed data). Averages followed by the same letter did not differ from each other by the Scott-Knott test at 5\% probability. Coefficient of variation (CV) $30.6 \%$; p-value $<0.01$

The occurrence of fungi is detrimental to seed quality and can cause germination drop and reduce vigor, which can affect the establishment of plants under cultivation. The fungus Rhizopus sp. is considered of low economic importance in wheat seeds as a contaminant, however, as it is a fast-growing pathogen covering the seeds, it hinders usually the detection of other pathogens.

The incidence and severity of pathogens vary according to location, temperature and humidity (Brancão, 2008; Celano, Machado, Jaccoud, \& Guimarães, 2012). Thus, it is important to monitor these factors in order to qualitatively and quantitatively observe the presence of pathogens associated with wheat seeds.

In addition to the control of plant pathogens under field conditions, technologies for monitoring the physical state of seeds can be implemented through health testing and sanitary treatment, which are fundamental to determine the causes of low germination, common in samples with high infection rates (Machado, 1982).

The fungus Cladosporium sp. is considered pathogenic to several plants and may reduce seed vigor (Rajput \& Aslam, 2005). Moreover, this pathogen has been reported in association with wheat seeds (Brancão et al., 2002; Duan, Wang, Zhu, \& Wu, 2007; Malaker, Mian, Bhuiyan, Akanda, \& Reza, 2008).

One of the shoot diseases of major concern is the wheat blast, caused by P. grisea. Its importance is due to the impact on reducing grain yield and quality, which can reach up to $50 \%$ (Reis et al., 2005). Although there was no high incidence of $P$. grisea in the genotypes analyzed, the presence of this pathogen in seeds is of concern for the regions of the State of Mato Grosso, where conditions are favorable for its development. When infection occurs at the beginning of flowering and grain filling, they present deformed, small and with specific low weight (Embrapa, 2004). The materials analyzed in this study that presented the incidence of $P$. grisea in the seeds were BRS Gralha azul with $0.25 \%$ and IPR Taquari TM with $59 \%$. Both materials with the incidence of $P$. grisea are cultivars with high grain yield in the State of Paraná, wide adaptation, technological quality.

The genotypes BRS Gaivota, LD 152109, WT 13086, FDS Virtude, BRS Gralha Azul, BRS Sabiá, BRS Graúna, TBIO Sintonia and BRS Pardela had the highest germination percentages between $98.3 \%$ and $87.3 \%$, while the lowest germination index was recorded for Taquari TM (22\%), followed by WT 11167 (37.3\%), TBIO Mestre (44.3\%). The other genotypes had intermediate level of germination, which indicates that the phytopathogens influenced the germination percentage for each wheat genotype evaluated (Figure 2). 


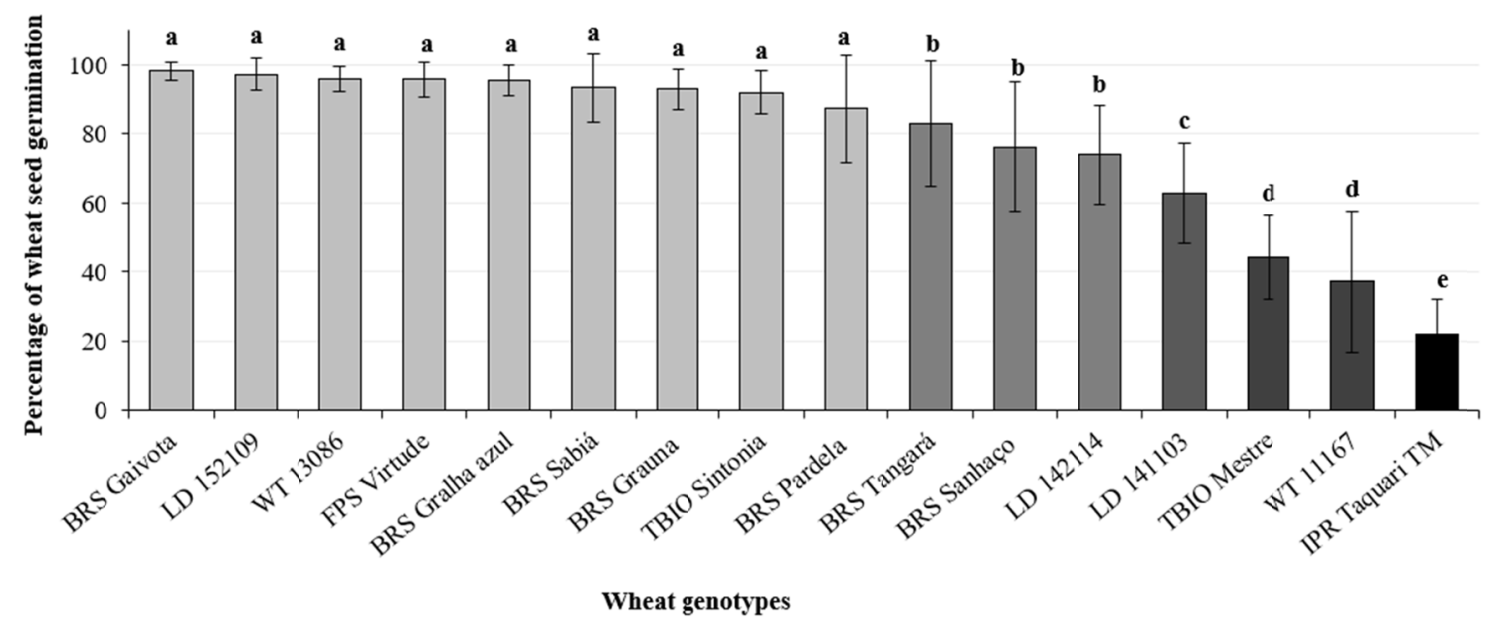

Figure 2. Percentage of wheat seed germination in 16 genotypes (unprocessed data). Averages followed by the same letter did not differ from each other by the Scott-Knott test at 5\% probability. CV 15.3\%; p-value $<0.01$

Although the presence of fungi such as Phoma sp. and Bipolaris sp. was not constant, it indicates the transport and association of disease-causing pathogens in several crops, causing economic damage, whether in grains or seeds. The materials that presented the highest incidence of Phoma sp. were LD $142114(0.75 \%)$ and BRS Tangará $(0.25 \%)$. Genotype LD 152109 was the only one to present the fungus Bipolaris sp. at $0.25 \%$ incidence.

Fungi of secondary importance such as Curvularia sp., Cladosporum sp., Mucor sp., Nigrospora sp., Trichothecium sp., Periconia sp., and Rhizopus sp. are part of the complex of grain-staining pathogens (Celano, Machado, Jaccoud, \& Guimarães, 2012). The genotypes BRS Graúna (2\%), WT 11167 (1.5\%), TBIO Sintonia and FPS Virtude (1\%), BRS Gaivota and BRS Sabiá $(0.5 \%)$ and BRS Tangará $(0.25 \%)$ incidence of the fungus Curvularia sp. Genotypes that presented incidence of the fungus Cladosporum sp. were BRS Gaivota (1.75\%) and BRS Gralha azul (1.25\%). The pathogen Mucor sp. showed a higher incidence in BRS Gaivota materials (32.25\%) and BRS Graúna (28.5\%). The pathogen Nigrospora sp. showed a higher incidence in the genotype IPR Taquari TM (11\%). Genotypes LD 142114 (6.25\%) and LD 152109 (2.75\%) presented a higher incidence of Trichothecium sp., Periconia sp., presented incidence only in the genotype BRS Sanhaço (0.25\%). Rhizopus sp. showed a higher incidence in genotypes LD 141103 (63.75\%), TBIO Mestre (62\%), WT 11167 (50\%), BRS Sanhaço (31.25\%) and BRS Tangará (28\%).

Pathogens can be considered the most active due to their ability to penetrate plant tissues and lodge internally. The seeds are vehicle of transport of the inoculum of fungi, the transmission rate of the pathogen will depend, the place where it is located and the amount of the inoculum in the seeds. The most effective way for the seedling that will originate to present infection is through the presence of the pathogen in the embryo of the seeds (De Sá et al., 2011).

Other factors that can influence the infection of pathogens in seeds, such as genotype, practices used in crop management, severity of infection in the parent plant as well as the phase of infection in the plant, insect infestation and the way of management during seed processing (MACHADO, 2012).

Intermediate fungi attack the grains before harvest and continue to grow and cause damage during storage. This category includes some species of Penicillium sp. and Fusarium sp. (Vecchia \& Castilhos-Fortes, 2007; Kobayasti et al., 2011). According to Medina et al. (2009), in the period after harvesting and during the transportation and storage of agricultural products, fungal growth can be influenced by many factors, mainly humidity level, temperature, aeration, insect damage, and storage time, among others. Moreover, the greatest effects of fungal development on stored grains and seeds are loss of germination power, loss of dry matter, mycotoxin production and change in nutritional value (Kobayasti et al., 2011).

\section{Conclusion}

The genera Aspergillus sp., Rhizopus sp., Penicillium sp., and Bipolaris sp. were the predominant phytopathogens in wheat seeds, with the first two presenting higher incidence percentages. Wheat seeds of the BRS Gralha azul and BRS Sabiá genotypes had higher incidence for different pathogens. On the other hand, WT 11167 and IPR Taquari TM genotypes presented the highest percentage of seeds with phytopathogens. Nine of 
the sixteen genotypes investigated had the highest germination percentages, which were between $98.3 \%$ and $87.3 \%$. The presence of fungi is detrimental to seed quality and may cause germination drop and reduce vigor, besides affecting the establishment of plants under cultivation.

\section{Acknowledgements}

Thanks to the Coordination for the Improvement of Higher Education Personnel (CAPES) for the granting of the scholarship to Puia, J.D.

Special thanks to in memorian Dr. Marizangela Rizzatti Ávila for their assistance during this study.

\section{References}

Barnett, H. L., \& Hunter, B. B. (1998). Illustrated genera of imperfect fungi. SaintPaul: American Phytopathological Society. Retrieved from https://www.cabdirect.org/cabdirect/abstract/19721103191

Barros, B. D. C., Castro, J. L. D., \& Patrício, F. R. A. (2006). Resposta de cultivares de trigo (Triticum aestivum L.) ao controle químico das principais doenças fúngicas da cultura. Summa Phytopathologica, 32(3), 239-246. https://doi.org/10.1590/S0100-54052006000300005

Brancão, M. F., Del Ponte, E. M., de Faria, C. R. J., Bernardi, N. L., \& Rossetto, E. A. (2008). Qualidade sanitária de sementes de trigo (Triticum aestivum L.) no Estado Do Rio Grande Do Sul: Safras 2004 e 2005. Current Agricultural Science and Technology, 14(2). Retrieved from https://periodicos.ufpel.edu.br/ojs2/ index.php/CAST/article/view/1910

Brancão, N., Nunes, C. D. M., Gastal, M. D. C., Raupp, A. A. A., Porto, M. P., \& Wendt, W. (2002). Ocorrência de fungos em sementes de sorgo, milho, soja e trigo. Embrapa Clima Temperado-Comunicado Técnico (INFOTECA-E). Retrieved from https://www.infoteca.cnptia.embrapa.br/bitstream/doc/744406/1/comuni cado76.pdf

Casa, R. T., Kuhnem, J. P. R., Bogo, A., Belani, A. M. M., Bolzan, J. M., Oliveira, F. S., \& Blum, M. M. C. (2012). Survey, survival and control of Alternaria alternata in wheat seeds. Revista Brasileira de Sementes, 34(3), 358-365. https://doi.org/10.1590/S0101-31222012000300001

Celano, M. M., Machado, J. D. C., Jaccoud Filho, D. D. S., \& Guimarães, R. M. (2012). Potential of water restriction technique for wheat seed health testing. Revista Brasileira de Sementes, 34(4), 613-618. https://doi.org/10.1590/S0101-31222012000400012

CONAB (Companhia Brasileira de Abastecimento). (2020). Acompanhamento da safra brasileira de grãos-Quinto levantamento, safra 2019/20. Retrieved March 15, 2020, from https://www.conab.gov.br/ info-agro/safras/graos/boletim-da-safra-de-graos

De Sá, D. A. C., Santos, G. R., Furtado, G. Q., Erasmo, E. A. L., \& Nascimento, I. R. (2011). Transporte, patogenicidade e transmissibilidade de fungos associados às sementes de pinhão manso. Revista Brasileira de Sementes, 33(4), 663-670. https://doi.org/10.1590/S0101-31222011000400008

Dhingra, O. D. (1985). Prejuízos causados por microrganismos durante o armazenamento de sementes. Revista Brasileira de Sementes, Brasilia, 7(1), 139-145. https://doi.org/10.17801/0101-3122/rbs.v7n1p139-145

Duan, C. X., Wang, X. M., Zhu, Z. D., \& Wu, X. F. (2007). Testing of seedborne fungi in wheat germplasm conserved in the national crop genebank of China. Agricultural Sciences in China, 6(6), 682-687. https://doi.org/10.1016/S1671-2927(07)60100-X

Dweba, C. C., Figlan, S., Shimelis, H. A., Motaung, T. E., Sydenham, S., Mwadzingeni, L., \& Tsilo, T. J. (2017). Fusarium head blight of wheat: Pathogenesis and control strategies. Crop Protection, 91, 114-122. https://doi.org/10.1016/j.cropro.2016.10.002

Embrapa (Empresa Brasileira de Pesquisa Agropecuária). (2004). Informações gerais sobre brusone em trigo e em cevada. Passo Fundo: Embrapa.

Fisher, M. C., Henk, D. A., Briggs, C. J., Brownstein, J. S., Madoff, L. C., McCraw, S. L., \& Gurr, S. J. (2012). Emerging fungal threats to animal, plant and ecosystem health. Nature, 484(7393), 186-194. https://doi.org/ 10.1038 /nature10947

Freire, F. C. O., Vieira, I. G. P., Guedes, M. I. F., \& Mendes, F. N. P. (2007). Micotoxinas: Importância na alimentação e na saúde humana e animal (p. 48, Documentos, 110). Fortaleza: Embrapa Agroindústria Tropical. Retrieved from http://www.cnpat.embrapa.br/cd/jss/acervo/Dc_110.pdf 
Kobayasti, L., \& Pires, A. P. (2011). Levantamento de fungos em sementes de trigo. Pesquisa Agropecuária Tropical, 41(4), 572-578. https://doi.org/10.5216/pat.v41i4.12388

Leslie, J. F., \& Summerell, B. A. (2008). The Fusarium laboratory manual. John Wiley \& Sons. Retrieved from https://books.google.com.br/books?hl=pt-PT\&lr=\&id=Yu3cBAAAQBAJ\&oi=fnd\&pg=PR3\&dq=The+Fus arium+laboratory + manual\&ots $=3 \mathrm{~K} 675 \mathrm{LUe} 3 \mathrm{p} \& \operatorname{sig}=8 \_1 \_\mathrm{aLFTfm} 3 \mathrm{t} 8 \mathrm{fRNKyBBtWuArvQ} \# \mathrm{v}=$ onepage $\& \mathrm{q}=\mathrm{T}$ he $\% 20$ Fusarium $\% 20$ laboratory $\% 20$ manual\& $\mathrm{f}=$ false

Machado, J. C. (2012). Patologia de sementes: Significado e atribuições. In N. M. Carvalho \& J. Nakagawa (Eds.), Sementes: Ciência, tecnologia e produção (pp. 524-590). Jaboticabal: FUNEP.

Machado, J. D. C. (1982). Controle de fitopatógenos associados a sementes. Informe Agropecuário, 8(91), 34-40. Retrieved from http://www.sidalc.net/cgi-bin/wxis.exe/?IsisScript=cibagro.xis\&method=post\&formato=2\& cantidad $=1$ \&expresion $=\mathrm{mfn}=029717$

Malaker, P. K., Mian, I. H., Bhuiyan, K. A., Akanda, A. M., \& Reza, M. M. A. (2008). Effect of storage containers and time on seed quality of wheat. Bangladesh Journal of Agricultural Research, 33(3), 469-477. https://doi.org/10.3329/bjar.v33i3.1606

MAPA (Ministério da Agricultura, Pecuária e Abastecimento). (2003). Portaria ${ }^{0} 131$, de 8 de Dezembro de 2003. Diário Oficial da República Federativa do Brasil. Brasília, DF.

McMullen, M., Bergstrom, G., De Wolf, E., Dill-Macky, R., Hershman, D., Shaner, G., \& Van Sanford, D. (2012). A unified effort to fight an enemy of wheat and barley: Fusarium head blight. Plant Disease, 96(12), 1712-1728. https://doi.org/10.1094/PDIS-03-12-0291-FE

Medina, P. F., Tanaka, M. A. D. S., \& Parisi, J. J. D. (2009). Sobrevivência de fungos associados ao potencial fisiológico de sementes de triticale (X. triticosecale Wittmack) durante o armazenamento. Revista Brasileira de Sementes, 31(4), 17-26. https://doi.org/10.1590/S0101-31222009000400002

Menten, J. O. M. (1995). Patógenos em sementes (p. 321). Ciba Agro, São Paulo, Brasil.

Neergaard, P. (1979). Seed pathology (2nd ed.). London: Macmillan.

Rajput, M. A., Pathan, M. A., Lodhi, A. M., Shah, G. S., \& Khanzada, K. A. (2005). Studies on seed-borne fungi of wheat in Sindh Province and their effect on seed germination. Pakistan Journal of Botany, 37(1), 181-185. Retrieved from https://pdfs.semanticscholar.org/7410/a10ebba81eb5285db5750e8a839af9219 840.pdf

Reis, E. M. (2001). Diagnose, patometria e controle de doenças de cereais de inverno. Universidade de Passo Fundo, Faculdade de Agronomia e Medicina Veterinária.

Reis, E. M., \& Casa, R. T. (1998). Patologia de Sementes de Cereais de Inverno (p. 88). Aldeia Norte, Passo Fundo, RS, Brazil.

Reis, E. M., \& Casa, R. T. (2005). Doenças do trigo. In H. Kimati, et al. (Eds.), Manual de fitopatologia (pp. 631-638). São Paulo: Agronômica Ceres.

Silva, R. R., Benin, G., Silva, G. O. da, Marchioro, V. S., Almeida, J. L. de, \& Matei, G. (2011). Adaptabilidade e estabilidade de cultivares de trigo em diferentes épocas de semeadura, no Paraná. Pesquisa Agropecuária Brasileira, 46(11), 1439-1447. https://doi.org/10.1590/S0100-204X2011001100004

Souza, L. C. D. de, Yamashita, O. M., \& Carvalho, M. A. C. de. (2007). Qualidade de sementes de arroz utilizadas no norte de Mato Grosso. Revista Brasileira de Sementes, 29(2), 223-228. https://doi.org/ $10.1590 / \mathrm{S} 0101-31222007000200029$

Vecchia, A. D., \& Castilhos-Fortes, R. D. (2007). Contaminação fúngica em granola comercial. Food Science and Technology, 27(2), 324-327. https://doi.org/10.1590/S0101-20612007000200020

Warham, E. J., Sutton, B. C., \& Butler, L. D. (1996). Seed testing of maize and wheat: A laboratory guide. CIMMYT. Retrieved from https://books.google.com.br/books?hl=pt-PT\&lr=\&id=_UiDLXC5UToC\&oi=fn $\mathrm{d} \& \mathrm{pg}=\mathrm{PT} 25 \& \mathrm{dq}=$ Seed + testing + of + maize + and + wheat $:+\mathrm{A}+$ laboratory + guide.$+\&$ ots $=4$ uaRuIrxad\&sig $=\mathrm{id} 7 \mathrm{u}$ O9HFAzLT9-Ky1SinvKE4-I0\#v=onepage\&q=Seed\%20testing\%20of\%20maize\%20and\%20wheat\%3A\%2 $0 \mathrm{~A} \%$ 20laboratory\%20guide. $\& \mathrm{f}=$ false 


\section{Copyrights}

Copyright for this article is retained by the author(s), with first publication rights granted to the journal.

This is an open-access article distributed under the terms and conditions of the Creative Commons Attribution license (http://creativecommons.org/licenses/by/4.0/). 